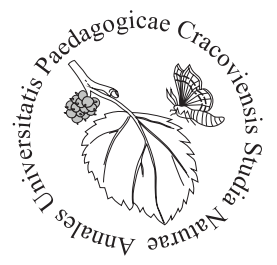

Andrzej Danel1* ${ }^{*}$, Joanna Puła²

${ }^{1}$ Faculty of Food Technology, Department of Chemistry, The H. Kołłataj University of Agriculture, Balicka St. 122, Kraków, Poland; ${ }^{*}$ rrdanela@cyf-kr.edu.pl

${ }^{2}$ Faculty of Agriculture and Economics, Department of Agroecology and Plant Production, The H.Kołłataj University of Agriculture, Mickiewicza 2 Ave, Kraków, Poland

\title{
Plants as a treasury of fragrant substances for food industry and perfumery
}

Introduction

Fragrant substances play an important role in our life. Every day we accidentally or deliberately smell hundreds or even thousands of natural and artificial compounds. Some of them exhibit pleasant aroma like vanilla in ice creams or constituents of top perfumes. Before we start to drink a good wine or whisky our noses are attacked with dozens of volatile chemical molecules preparing our tongues for subsequent flavour experiences. On the other hand sweat components or volatiles released from some mould cheeses or fermented food like 'surströmming' arouse disgust in some persons but a small amount of very bad smelling organic sulphur compounds like tetrahydrothiophene in natural gas we use in our kitchen can save somebody life in case of gas leakage. It would be difficult to imagine our existence without various aromas.

It seems that eating is one of the biggest pleasures we can experience in our life. Even in the Holy Bible there is a statement "There is nothing better for a man than taking meat and drink, and having delight in his work". Eating is a multisensory experience. The very first contact is with eyes, next the senses of taste and smell are engaged. In the paper published in Science the authors claim that people are able to recognise more than one trillion of olfactory stimuli (Bushdid et al., 2014). These results are breathtaking and in the strong contrast with many previous statements sometimes not proven by experiments. In popular literature we can still find relatively old information that people can distinguish just about 3.000-10.000 odours (Crocker, Henderson, 1927).

Food technologists very often encounter the problem of destroying food aroma during thermal food processing. The volatile compounds are lost and the flavour of 
the resulting product may be different from the starting components. At present due to the fragrant food additives we are able to a certain extent restore these aromas. Addition of some synthetic or natural aromas to food products increases their tastiness and sensory attractiveness. It should be remembered that there are two ways in which we smell - orthonasal and retronasal route (Spence, 2017). This short review is devoted to plant-derived aromatic substances applied as food additives and in some cases as materials for perfume industry as well.

\section{Essential oils - preparation}

Essential oils belong to the natural fragrant materials widely applied in food industry and in pharmaceutical and perfumery ones too. These materials can be obtained in many ways. The most important ones are extractions with various solvents like $n$-hexane $\mathrm{C}_{6} \mathrm{H}_{14}$, ethyl acetate $\mathrm{CH}_{3} \mathrm{COOEt}$, methylene chloride $\mathrm{CH}_{2} \mathrm{Cl}_{2}$, florasol (1,1,1,2-tetrafluoroethane) or supercritical carbon dioxide. The last solvent is definitely environmental friendly and safe as far as residues in the final product. In food industry it is used for removal of caffeine from coffee beans and green tea (Kim et al., 2010).

Another example is the extraction of essential from Lavandula $\times$ hybrida Rever. (Lavandin) flowers with supercritical carbon dioxide. The two most important components of this oil are linalool and linalyl acetate applied in food industry and as biocides as well (Kamali et al., 2015). Supercritical carbon dioxide was also applied in isolation of essential oils from Flixweed, Eucalyptus globulus Labill., Mentha xpiperita L. (Zekovic et al., 2009; Mahdavi et al., 2015; Singh et al., 2016). Other examples can be found in some review papers on this subject (Xu et al., 2011; Capuzzo et al., 2013; Manjare et al., 2019).

The second important method of essential oil isolation is steam distillation. The steam flow is passed through the plant material (bark, flowers, roots, leaves, peel, berries, rhizome) placed in a glass flask or steel container and removes volatile compounds with subsequent condensation. The distillate is collected in receiver and an essential oil is separated from the water phase. The resulted oil can be subjected to fractional distillation and rectification. In some cases the cooling of the resulted oil results in crystallisation of some constituents. Steam distillation process can be supported with microwave heating of the plant material/water mixture for more effective isolation of fragrant material (Chemat et al., 2006; Sahraoui et al., 2008; Moradi et al., 2018). Another group of researchers applied solvent free microwave extraction SFME of essential oils from plant material (Lucchesi et al., 2018). The authors significantly reduced the time of oil extraction in comparison with traditional hydro-distillation method. At present a microwave reactor is a standard tool for chemists. Beside it ultrasound assisted reactions are more and more popular in organic and analytical chemis- 
try (Capelo-Martinez, 2009; Cravotto et al., 2018). This technique is a valuable tool for extraction of essential oils and other plant metabolites. The details of this procedure and its application in food industry, cosmetics and pharmacy can be found in a recent review paper (Chemat et al., 2017).

It would be good to mention probably the oldest method of essential oils preparation based on the cold pressing of plant material like olives or citrus peels. The most important products obtained in this way are orange, lemon, grapefruit and bergamot essential oils which are widely employed in food and cosmetic industry.

In case of danger that some constituents of essential oils can be decomposed at the temperature of steam distillation the procedure of maceration can be applied. One of the oldest and very effective though very tedious is enfleurage. This method is based on extracting of fragrant compounds from plant material (usually flower petals or whole flowers) with animal fat like lard or tallow and leaving the whole for a few days. After this time the flowers are removed and new ones are mixed with lipids. This procedure is repeated up to the saturation of fat with essential oils. After removing the flowers the fat is mixed with ethyl alcohol. The components of essential oils are dissolved in it and the insoluble fat is separated off. The residue resulted after the evaporation of the alcohol is called an absolute. The technique of enfleurage is almost abandoned and replaced with solvent extraction (Surburg, Penten, 2006). Such an example is jasmine absolute, a very valuable ingredient for perfumery industry. At present it is prepared by double or triple extraction of jasmine blossoms with $n$-hexane. One needs to collect manually 8.000000 blossoms to obtain $1 \mathrm{~kg}$ of jasmine absolute (Konopski, Koberda, 2003).

\section{The chemical constituents of essential oils}

Essential oils applied as food additives or products for fragrant composition in perfume industry are complicated mixtures of many compounds. For example the recent investigations on volatile and semi-volatile compounds in various citrus oils (ex. Citrus limon (L.) Burm., C. sinensis (L.) Osbeck, C. medica L.) based on gas chromatography coupled to mass spectrometry (GC-MS) revealed the presence of 200-400 compounds (Bozkurt et al., 2017; Gonzales-Mas et al., 2019). The essential oils extracted from Rosa $\times$ centifolia L. or $R$. $\times$ damescena Mill. are one of the most expensive ingredients applied in cosmetics industry. The amount of volatile compounds varies depend on the literature source. Some authors reported 32 compounds based on GC and GC-MS chromatography. Among them the most abundant were citronellol, geraniol and nerol (Ahmad et al., 2009). The other group reported 50 volatiles in Damascene rose oil (Naquvi et al., 2014). A recent review on rose essential oil or 'liquid gold' constituents suggests that investigation on this subject is far to be finished (Nunes, Graca, 2017). 
<smiles>C/C=C/c1ccc(OC)cc1</smiles>

1<smiles>CC(C)=CCC/C(C)=C\C=O</smiles>

6<smiles>C=CCc1ccc(O)c(OC)c1</smiles>

11<smiles>O=Cc1ccccc1</smiles>

2<smiles>CC(C)=CCCC(C)CC=O</smiles>

7<smiles>C=C(C)C1CC=C(C)C(=O)C1</smiles>

8<smiles>C=CC(C)(CCC=C(C)C)OC(C)=O</smiles>

13<smiles>O=C/C=C/c1ccccc1</smiles>

4<smiles>C=C(C)[C@H]1CC=C(C)C(=O)C1</smiles><smiles>CC12CCC(O1)C(C)(C)C2</smiles>

9

10<smiles>CC1=CCC2CC1C2(C)C</smiles>

14<smiles>CC(C)=CCC/C(C)=C/C=O</smiles>

5

Fig. 1. Chemical structures of some isolates from essential oils: 1) anethole, 2) benzaldehyde, 3) camphor, 4) cinnamaldehyde, 5) citral A, 6) citral B, 7) citronellal, 8) (S)-carvone, 9) (R)-carvone, 10) eucalyptol, 11) eugenol, 12) (R)-(+)-limonene, 13) linalyl acetate, 14) menthol, 15) pinene (Source: Rutkowski et al., 2003; Kołodziejczyk, 2013)

In some cases the content of some fragrant materials is quite high so some essential oils are subjected to fractional distillation or crystallisation to obtain valuable materials for food industry, perfumery or organic synthesis. The significant majority of them are terpenes hydrocarbons or their monofunctional derivatives. Beside them we can find esters, aromatic aldehydes, phenols, ketones, ethers and nitrogen, oxygen and sulphur containing heterocycles. 
Some important isolates 1-15 from essential oils are listed in figure 1 (Rutkowski et al., 2003; Kołodziejczyk, 2013). The worldly production of anise essential oil is estimated over 400 tonnes and the content of trans-anethol 1 is ca. 70-95\% depending on the plant source. Anethol can be prepared in a synthetic way too. It is used as a food additive to some alcoholic beverages like absinth, anisette and raki. The last one is an alcoholic drink popular in Turkey (Ashurst, 1999). Benzaldehyde 2 is obtained either synthetically or from natural cinnamaldehyde 4 in the reaction with sodium hydroxide (Wiener, Pittel, 1985; Surburg, Panten, 2006). It can be also prepared from amygdalin extracted from some kernels like apricot or bitter almonds (Passos, Ribeiro, 2010). Cinnamaldehyde 4 is obtained from cinnamon bark Cinnamomum verum J.Presl or C. cassia (L.) J.Presl through steam distillation. There are some alternative synthetic pathways to prepare this compound like aldol condensation of benzaldehyde and acetic aldehyde but due to the high worldly production of cinnamic bark the isolation is more economic. Benzaldehyde 2 and cinnamaldehyde 4 are applied in food industry as flavours in chewing gums, cakes, bakery aromas or ice creams. Camphor 3 can be isolated from C. camphora Ness et Eberm tree grown in China, Vietnam, Japan and Taiwan. As a food additive natural camphor is popular in India (Aguilar et al., 2008). It can be also synthesised from natural pinene 15. Beside it this terpene is used for synthesis of other fragrant substances like terpineol or verbenone. These substances can be prepared either via chemical or microbial oxidation of pinene (Rozenbaum et al., 2006; Praskoso et al., 2018).

Citronella grass Cymbopogon nardus (L.) Rendle is a rich source of citral A (geranial) 5, citral B (neral) 6 and citronellal 7. These compounds are used in food industry as lemon, lime and orange flavorings for ice creams, candies and baked goods (Winter, 2009). Geranial and neral were also found in hop essential oil. They are reduced by yeast into geraniol and nerol and in part these compounds are responsible for beer flavour (Tressl et al., 1987). Two carvone enantiomers 8 and 9 are used as food additives, insects repellents and building blocks in asymmetric organic synthesis (Cravalho, Fonesca, 2006). These compounds can be isolated from Carum carvi L. and Mentha spicata L., respectively. The major application of eucalyptol 10 involves candies, aromatic balms or mouthwash (Cameron, Easton, 2000). Just recently eucalyptol was applied as solvent in synthesis of heterocyclic compounds (Campos et al., 2019). Eugenol 11 is known to possess antiseptic properties and is used in dentistry. Its application as food additive is relatively limited due to the very strong odour. This compound is obtained from oil of clove derived from steam distillation of flower buds, leaves and steam of Syzygium aromaticum (L.) Merr. \& Perry. Chatterjee and Paramita described investigations on application of eugenol as natural antioxidant in mayonnaise (Chatterje, Bhattacharje, 2015). Moreover it can be a starting material for synthesis of vanillin - a valuable natural fragrant substance (Lampman et al., 1977). (R)-(+)-li- 
monene 12 is produced on the biggest scale in the world. The annual production of this fragrant compound in Brazil and Florida is estimated at $75.000 \mathrm{t}$ (Taylor, 2002). Due to this abundant amount this compound with the smell of orange or lemon is applied not only in food industry and perfumery but it is used as a solvent for grease removal and a paint stripper too. The bergamot essential oil derived from bergamot oranges contains limonene 12 (30.7\%) and linalyl acetate 13 (30.1\%), respectively (Sawamura et al., 2006). The last compound found a vast application in perfume industry (Fahlbush et al., 2003). Essential oils from Mentha arvensis L. and M. xpiperita L. contain menthol 14 which found multiple applications in many consumer products like cosmetics, drugs and tobacco flavour additive (Aldadyan, Samet, 2018).

\section{Diamonds among fragrant materials}

In some essential oils the content of a single fragrant substance can be very high. Such an example is $(R)-(+)$-limonene. In citrus, orange or lemon essential oils its amount varies within $65-90 \%$. On the other hand there are valuable aromatic substances which exist in very small amounts in plant material. Some of them are depicted in figure 2. One of the examples is nootkatone 16 which can be found in grapefruit, orange and mandarin oranges essential oils. It can be isolated from these sources but due to tiny amount of $0.01-0.5 \%$ the price of the natural compound is very high and varies between 4.000-6.500 Euro/kg. Pure compound found an application as insect repellent and a food additive approved by FDA (Food and Drug Administration) as well (Jordan et al., 2012). To avoid high costs of natural compound, alternative synthetic methods were developed including biotechnological based ones (Fratz et al., 2009).

Even a more expensive food flavour additive and a diet supplement is raspberry ketone 17. It is a natural compound which can be found in cranberries, blackberries and raspberries. In the last example it occurs in the amount of $1-4 \mathrm{mg} / \mathrm{kg}$ so the extraction from natural resources is useless from economical point of view because the estimated price is ca. 20.000\$/kg (Beekwilder et al., 2007). There is a big demand for this flavour ingredient as a food additive and a diet supplement as well. Thus raspberry ketone can be synthesised from simple starting materials such as $p$-hydroxbenzaldehyde 22 and acetone 23 resulting chalcone 24 which can be reduced with cheap reagents like nickel boride and hydrogen $\mathrm{Ni}_{2} \mathrm{~B} / \mathrm{H}_{2}$ under atmospheric pressure yielding the final compound 17 (Fig. 3) (Bandarenko, Kovalenko, 2014).

Unfortunately this product cannot be recognised as natural in spite of the identical properties with the raspberry ketone obtained from natural resources. To fulfil these demands, methods based on natural substrates and preparation processes as natural as possible are in great demand. Joulain and Fuganti published a procedure employing a baking yeast for reduction of a double bond in 4-( $p$-hydroxyphenyl)but-3-en-2-one 24 yielding raspberry ketone 17 in 56\% yield (Joulian, Fuganti, 1999). Acetone 23 can 
<smiles>C=C(C)[C@@H]1CCC2=CC(=O)CC(C)C2(C)C1</smiles>

16

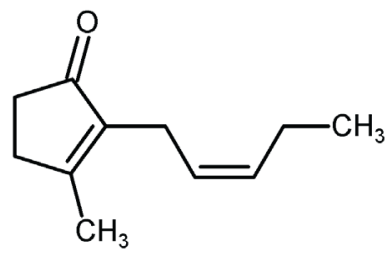

19<smiles>CC(=O)CCc1ccc(O)cc1</smiles>

17

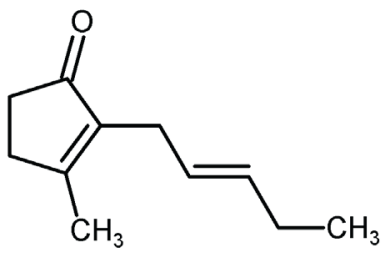

20<smiles>CC(C)=C[C@H]1CC(C)CCO1</smiles>

18<smiles>COc1cc(C=O)ccc1O</smiles>

21

Fig. 2. Chemical structures of some expensive fragrant materials: 16) nootkatone, 17) raspberry ketone, 18) rose oxide, 19) cis-jasmone, 20) trans-jasmone, 21) vanillin (Source: Ruzicka, Pfeiffer, 1933; Berger, 2007; Fratz et al., 2009; Alsters et al., 2010; Bandarenko, Kovalenko, 2014)<smiles>CC(=O)/C=C/c1ccc(O)cc1</smiles>

22

23

24

Fig. 3. Synthesis of raspberry ketone: a) $\mathrm{NaOH}$, r.t. $24-48$ hrs; b) $\mathrm{Ni}_{2} \mathrm{~B}$ or baker yeast (Source: Joulain, Fugati, 1999; Bandarenko, Kovalenko, 2014)

be obtained from microbial synthesis (Sauer, 2016). Natural $p$-hydroxybenzaldehyde 22 can be extracted from sorghum shoots (Sorghum vulgare Pers.) (Bove, Conn, 1961).

Rose oxide 18 is one of the constituent of rose essential oil obtained from Rosa $\times$ damascena and $R$. xcentifolia as well. Due to the very high price of the previously mentioned essential oils, some synthetic procedures were developed to prepare this compound because it is used in contemporary perfume compositions (Alsters et al., 2010). Rose oxide was found also in some Muscat wines and is one of the components responsible for floral-green flavour of those wines (Boelens et al., 1993).

The similar situation is with one of the constituent of the jasmine essential oil namely cis-jasmone 19 used in the creation of high quality perfumes. The content of 
this compound in jasmine essential oil varies at $2.6-3.4 \%$ so the isolation is definitively unprofitable (Clarke, 2008). It was discovered over 100 years ago and since that time many synthetic pathways have been developed to fulfil demand of perfume producers (Hesse, 1899). The synthetic jasmone is frequently a mixture of cis/trans 19/20 isomers (Ruzicka, Pfeiffer, 1933).

The last, but not the least example in this small gallery of natural fragrant materials is vanillin 21. The natural compound can be extracted from Vanilla planifolia Andrews grown in Madagascar. Unfortunately the natural resources are not sufficient to satisfy the demands of the market so many synthetic procedures were developed to supply this valuable product for food and perfumery industry. Thus synthetic vanillin can be prepared on industrial scale either from eugenol, guaiacol or from lignin a side product from cellulose industry (Berger, 2007). There is also a technological procedure of vanillin preparation from cow dung. The author of the procedure - Japanese scientist Mayu Yamamoto was awarded with Ig-Nobel prize for this outstanding achievement in 2008 (Yamamoto et al., 2008). Natural vanillin extracts are expensive so there is a danger that synthetic vanillin can be used to adulteration of natural extract. To avoid these problems numerous analytical techniques are applied including authentication with plant DNA (Philippe et al., 2019).

\section{Conclusions}

This very short review gives a slight glimpse on the application of fragrant substances of plant origin in contemporary food and perfume industry. At present as a whole 2.000-3.000 flavouring chemicals - both natural and synthetic are used commercially. The search and analysis of natural fragrant substances is especially challenging due to the fact that their content in plant or animal material is sometimes on the verge of a homeopathic one. On the other hand the rapid progress in modern analytical techniques gives birth to hope that many new aromatic molecules will be isolated and characterised in the future. Moreover we have to remember that a lot of organic chemists from academic and industrial laboratories constantly modify known structures and synthesise new molecules with interesting fragrant properties which do not exist in nature, so we can expect new olfactory experiences.

\section{Conflict of interest}

The authors declare no conflict of interest related to this article.

\section{References}

Aguilar, F., Autrup, H., Barlow, S., Castle, L., Crebelli, R., Dekant, W., Engel, K.-H., Gontard, N., Gott, D., Grilli, S., Gürtler, R., Larsen, J.Ch., Leclercq, C., Leblanc, J.-C., Malcata, X., Mennes, W., Milana, M.R., Pratt, I., Rietjens, I., Tobback, P., Toldrá, F. (2008). Opinion of the scientific panel on food 
additives, flavourings, processing aids and materials in contact with food on a request from the commission. The European Food Safety Authority Journal, 729, 1-15.

Ahmad, A., Sahoo, D., Ahmad, J., Tandon, S.(2009). GC-MS composition of rose oil (Rosa damascena) of different agro climatic regions of North India. Asian Journal of Chemistry, 21(6), 4643-4647.

Aladadyan, L., Samet, J.M. (2018). Tabacco products. Chapter 11. In: An Overview of FDA Regulated Products. From drugs and cosmetics to Food and Tabacco, 231-250. Academic Press. DOI: 10.1016/ B978-0-12-811155-0.00011-9.

Alsters, P.L., Jary, W., Nardello-Rataj, V., Aubry, J.M. (2010)."Dark” singlet oxygenation of $\beta$-Citronellol: A key step in the manufacture of rose oxide. Organic Process Research \& Development, 14, 259. DOI: $10.1021 /$ op $900076 \mathrm{~g}$

Ashurst, P.A. (1999). Food flavorings. Switzerland: Springer, Aspen Publishers, p. 128.

Bandarenko, M., Kovalenko, V. (2014). Synthesis of raspberry and ginger ketone by nickel boride-catalyzed hydrogenation of 4-arylbut-3-en-2-ones. Zeitschrift für Naturforschung B A Journal of Chemical Sciences, 69b, 885-888. DOI: 10.5560/znb.2014-4118

Berger, R.G. (2007). Flavours and Fragrances: Chemistry, Bioprocessing and Sustainability. Germany: Springer, p. 294. DOI: 10.1007/b136889.

Beekwilder, Van der Meer, I.M., Sibbesen, O., Broekgaarden, Quist I., Mikkelsen, D.J., Hall, R.D. (2007), Microbial production of natural raspberry ketone. Biotechnology Journal, 2, 1270-1279. DOI: 10.1002/biot.200700076.

Boelens, M.H., Boelens, H., Van Gemert, L.J. (1993). Sensory properties of optical isomers. Perfumer \& Flavorist, 18, 1-15.

Bove, C., Conn, E.E. (1961). Metabolism of aromatic compounds in higher plants. II. purification and properties of the oxynitrilase of Sorghum vulgare. Journal of Biological Chemistry, 236(1), 207-210.

Bozkurt, T., Gülnaz, O., Aka Kaçar, Y. (2017). Chemical composition of the essential oils from some citrus speciesand evaluation of the antimicrobial activity. Journal of Environmental Science, Toxicology and Food Technology, 11(10), 1-8. DOI: 10.9790/2402-1110XXXXX

Bushdid, C., Magnasco, M.O., Vosshall, L.B., Keller, A. (2014). Humans can discriminate more than one trillion olfactory stimuli. Science, 343(6177), 1370-1372. DOI: 10.1126/science.1249168

Cameron, G.C., Easton, S. (2000). Eucalyptol. Perfumer \& Flavorist, 25, 6-16.

Campos, J.F., Scherrmann, M.-C., Berteina-Raboin, S. (2019). Eucalyptol: a new solvent for the synthesis of heterocycles containing oxygen, sulfur and nitrogen. Green Chemistry, 21, 1531-1539. DOI: $10.1039 / \mathrm{C} 8 \mathrm{GC} 04016 \mathrm{H}$

Capelo-Martinez, J-L. (2009). Ultrasound in chemistry. Analytical applications. Weinheim: Wiley VCH.

Capuzzo, A., Maffei, M.E., Occhipinti, A. (2013). Supercritical fluid extraction of plant flavors and fragrances. Molecules, 18, 7194-7238. DOI: 10.3390/molecules 18067194

Carvalho, C.C.C.R., Fonseca, M.M.R. (2006). Carvone: Why and how should one bother to produce this terpene. Food Chemistry, 95, 413-422. DOI: 10.1016/j.foodchem.2005.01.003

Chatterjee, D., Bhattacharjee, P. (2015). Use of eugenol-lean clove extract as a flavoring agent and natural antioxidant in mayonnaise: product characterization and storage study. Journal of Food Science and Technology, 52(8), 4945-4954. DOI: 10.1007/s13197-014-1573-6

Chemat, F., Lucchesi, M.E., Smadja, J., Favretto, L., Colnaghi, G., Visinoni, F. (2006). Microwave accelerated steam distillation of essential oil from lavender: A rapid, clean and environmentally friendly approach. Analytica Chimica Acta, 555(1), 157-160. DOI: 10.1016/j.aca.2005.08.071.

Chemat, F., Rombaut, N., Sicaire, A.G., Meullemiestre, Fabiano-Tixier, A.S., Abert-Vian, M. (2017). Ultrasoun assisted extraction of food and natural products. Mechanisms, techniques, combination, protocols and applications. A review. Ultrasonics Sonochemistry, 34, 540-560. 
Clarke, S. (2008). Composition of essential oils and other materials. In: Essential Chemistry for Aromatheraphy Churchill Livingstone. Elsevier Ltd., 190. DOI: 10.1016/B978-0-443-10403-9.X000

Cravotto, G., Delattre, F., Leveque, J-M., Cintas, P. (2018). Organic sonochemistry: Challenges and perspectives for the $21^{\text {st }}$ century. Springer.

Crocker, E.C., Henderson, L.F. (1927). Analysis and classification of odors: An effort to develop a workable method. The American Perfumer \& Essential Oil Review, 22, 325-327.

Fahlbusch, K.-G., Hammerschmidt, F.-J., Panten J., Pickenhagen, W., Schatkowski, D., Bauer, K., Garbe, D., Surburg, H. (2003). Flavors and Fragrances. In: Ullmann's Encyclopedia of Industrial Chemistry. Wiley-VCH Verlag GmbH \& Co. KGaA. DOI: 10.1002/14356007.a11_141

Fratz, M.A., Berger, R.G., Zorn, H. (2009). Nootkatone - A biotechnological challenge. Applied Microbiology and Biotechnology, 83(1), 35-41. DOI: 10.1007/s00253-009-1968-x

González-Mas, M.C., Rambla, J.L., M., López-Gresa, P.M., Blázquez, A., Granell, A. (2019). Volatile compounds in citrus essential oils. A comprehensive review. Frontiers in Plant Science, 10(12), 00012. DOI: $10.3389 /$ fpls.2019.00012

Hesse, A. (1899). Ueber ätherisches Jasminblüthenöl. III. Berichte der Deutschen Chemischen Gesellschaft, 32, 2611-2620. DOI:10.1002/cber.18990320313.

Jordan, R.A., Schulze, T.L., Dolan, M.C. (2012). Efficacy of plant-derived and synthetic compounds on clothing as repellents against Ixodes scapularis and Amblyomma americanum. Journal of Medical Entomology, 49(1), 101-106.

Joulian, D., Fuganti, C. (1999). Process for preparing butanone derivatives. US Patent. US 005,908,770A.

Kamali, H., Aminimoghadamfarouj, N., Golmakani, E., Nematollahi, A. (2015). The optimization of essential oils supercritical $\mathrm{CO}_{2}$ extraction from Lavandula hybrida through static-dynamic steps procedure and semi-continuous technique using response surface method. Pharmacognosy Research, 7(1), 57-65. DOI: 10.4103/0974-8490.147209

Kim, W-J., Kim, J-D., Oh, S-G. (2007). Supercritical carbon dioxide extraction of caffeine from korean green tea. Separation Science and Technology, 42(14), 3229-3242. DOI: 10.1080/01496390701513008

Kołodziejczyk, A. (2013). Naturalne zwiazki organiczne. Warszawa: Wydawnictwo Naukowe PWN, s. 649-651. [In Polish]

Konopski, L., Koberda, M. (2003). Feromony człowieka. Środki komunikacji chemicznej między ludźmi. Warszawa: Wydawnictwo Naukowe Scholar. [In Polish]

Lampman, G.M., Andrews, J., Bratz, W., Hanssen, O., Kelley, K., Perry, D., Ridgeway, A. (1977). Preparation of vanillin from eugenol and saw dust. Journal of Chemical Education, 54(12), 776. DOI: 10.1021/ed054p776.

Mahdavi Ara, K., Jowkarderis, M., Raofie, F. (2015). Optimization of supercritical fluid extraction of essential oils and fatty acids from flixweed (Descurainia sophia L.) seed using response surface methodology and central composite design. Journal of Food Science and Technology, 2(7), 4450-4458. DOI: $10.1007 /$ s13197-014-1353-3

Manjare, S.D., Kabir, D. (2019). Supercritical fluids in separation and purification: A review. Materials Science for Energy Technologies, 2, 463-484. DOI: 10.1016/j.mset.2019.04.005

Moradi, S., Fazlali, A., Hamedi, H. (2018). Microwave-assisted hydro-distillation of essential oil from rosemary: comparison with traditional distillation. Avicenna Journal of Medical Biotechnology, 10(1), $22-28$.

Naquvi, K.J., Ansari, S.H., Najmi, A.K. (2014). Volatile oil composition of Rosa damascena Mill. (Rosaceae). Journal of Pharmacognosy and Phytochemistry, 2(5), 177-181.

Nunes, H.S., Graça, M. (2017). Rosa damascena essential oils: a brief review about chemical composition and biological properties. Trends in Phytochemical Research, 1(3), 111-128. 
Passos, M.L., Ribeiro, C.P. (2010). Innovation in food engineering: new techniques and products. Florida: CRC Press. p. 87.

Philippe, F., Dubrulle, N., Giraud, N. (2019). A major stake for the future: Vanilla authentication with DNA. Perfumer \& Flavorist, 44, 52-58.

Prakoso, T., Hanley, J., Soebianta, M.N., Soerawidjaja, T.H., Indarto A. (2018). Synthesis of terpineol from a-pinene using low-price acid catalyst. Catalysis Letters, 148(2), 725-731. DOI: 10.1007/ s10562-017-2267-2.

Rozenbaum, H.F., Patitucci, M.L., Antunes, O.A.C., Pereira, N. (2006). Production of aromas and fragrances through microbial oxidation of monoterenes. Brazillian Journal of Chemical Engineering, 23(3), 273-279. DOI: 10.1590/S0104-66322006000300001.

Rutkowski, A., Gwiazda, S., Dąbrowski, K. (2003). Kompendium dodatków do żywności. Konin: Hortimex, s. 362-363.[In Polish]

Ruzicka, L., Pfeiffer, M. (1933). Über Jasminiriechstoffe I. Die Konstitution des Jasmons. Helvetica Chimica Acta, 16, 1208-1214. DOI: 10.1002/hlca.193301601153. [In German]

Sahraoui, N., AbertVian, M., Bornard, I., Boutekedjiret, C., Chemat, F. (2008). Improved microwave steam distillation apparatus for isolation of essential oils: Comparison with conventional steam distillation. Journal of Chromatography A, 1210(2), 229-233. DOI: 10.1016/j.chroma.2008.09.078

Sauer, M. (2016). Industrial production of acetone and butanol by fermentation - 100 years later. Federation of European Microbiological Societies Microbiology Letters, 363, fnw134. DOI: 10.1093/femsle/ fnw134

Sawamura, M., Onishi, J., Ikemoto, J., Tu, N.T.M., Phi, N.T.L. (2006). Characteristic odour components of bergamot (Citrus bergamia Risso) essential oil. Flavour and Fragrance Journal, 21(4), 609-615. DOI: $10.1002 /$ ff. 1604

Singh, A., Ahmad, A., Bushra, R. (2016). Supercritical carbon dioxide extraction of essential oils from leaves of Eucalyptus globulus L., their analysis and application. Analytical Methods, 8, 1339-1350. DOI: 10.1039/C5AY02009C

Spence, C. (2017). Gastrophysics. The new science of eating. United Kingdom: Penguin Random House UK.

Surburg, H., Panten, J. (2006). Common fragrance and flavor materials. Wiley-Vch.

Taylor, A.J. (2002). Food Flavour Technology. CRC Press., p. 147.

Tressl, R., Kossa, M., Koppler, H. (1987). Changes of aroma compounds during processing of hops. EBC Symposium Hops, 116-119.

Winter, R. (2009). A consumer's dictionary of food additives. Three Rivers Press, p. 81.

Wiener, C., Pittet, A.O. (1986). Process for preparing natural benzaldehyde and acetaldehyde, natural benzaldehyde and acetaldehyde compositions, products produced thereby and organoleptic utilities therefor. US Patent. 4,617,419.

Xu, L., Zhan, X., Zeng, Z., Chen, R., Li, H., Xie, T., Wang, S. (2011). Recent advances on supercritical fluid extraction of essential oils. African Journal of Pharmacy and Pharmacology, 5(9), 1196-1211. DOI: 10.5897/AJPP11.228

Yamamoto, M., Futamura, Y., Fujioka, K., Yamamoto, K. (2008). Novel production method for plant polyphenol from livestock excrement using subcritical water reaction. International Journal of Chemical Engineering, 603957. DOI: 10.1155/2008/603957

Zeković, Z., Lepojević, Z., Milić, S., Aadamivić, D., Mujić, I. (2009). Supercritical CO 2 extraction of mentha (Mentha piperita L.) at different solvent densities. Journal of the Serbian Chemical Society, 74(4), $417-425$. 
Streszczenie

Artykuł poświęcony jest niektórym aspektom substancji zapachowych pochodzenia roślinnego, stosowanych jednocześnie $\mathrm{w}$ przemyśle spożywczym i perfumeryjnym. Od starożytności opracowano wiele technik ekstrakcji w celu uzyskania olejków eterycznych. Niektóre z nich są nadal stosowane. Nowe ekstrakcje, takie jak: mikrofalowe lub ultradźwiękowe, są coraz bardziej popularne i pozwalają zaoszczędzić czas oraz koszty. Niezależnie od procedury powstałe olejki eteryczne są źródłem wielu związków chemicznych, tzw. izolatów. Mogą one być stosowane jako dodatki do żywności lub jako materiały wyjściowe do syntezy organicznej. Niektóre substancje zapachowe występują w bardzo małych ilościach w materiale roślinnym, dlatego ekstrakcja nie jest opłacalna ekonomicznie, ale po ustaleniu ich struktur chemicznych i opracowaniu procedur syntetycznych, w niektórych przypadkach są one pozyskiwane na skalę przemysłową. Substancje opisane poniżej to tylko niewielka część z 2000-3000 pachnących cząsteczek, które sprawiają, że nasze życie jest przyjemniejsze, zarówno w jedzeniu, jak i perfumach.

Key words: essential oils, extraction techniques, food additives, fragrant substances.

Received: [2019.05.06]

Accepted: [2019.11.22] 